K A N D A I

\begin{tabular}{|l|l|l|}
\hline Volume 17 & No. 2, November 2021 & Halaman 190-203 \\
\hline
\end{tabular}

\title{
INTERLANGUAGE PRODUCED BY JUNIOR HIGH SCHOOL STUDENTS IN RECOUNT TEXT \\ (Interlanguage (Bahasa Antara) yang Dihasilkan oleh Siswa Sekolah Menengah Pertama dalam Teks Rekon)
}

\section{Ni Luh Putu Sri Adnyani, Putu Pande Novita Sari, Ni Komang Arie Suwastini, \& Putu Kerti Nitiasih Universitas Pendidikan Ganesha Jl. A Yani No. 67 Singaraja, Bali, Indonesia Pos-el: niluhputusriadnyani@gmail.com}

(Diterima: 4 Agustus 2020; Direvisi: 5 Maret 2021; Disetujui: 9 Agustus 2021)

\begin{abstract}
Abstrak
Karangan yang ditulis oleh siswa sekolah menengah pertama mengandung kalimat-kalimat salah yang menggambarkan bahasa mereka. Bahasa yang dihasilkan oleh siswa-siswa ini biasa dirujuk sebagai interlanguage (bahasa antara). Apakah bahasa pertama atau bahasa sasaran memengaruhi kesalahan-kesalahan tersebut? Penelitian ini bertujuan untuk mendeskripsikan interlanguage yang digunakan oleh siswa-siswa yang mempelajari Bahasa Inggris sebagai bahasa asing dalam teks rekon. Subjek penelitian ini terdiri atas 20 orang siswa sekolah menengah pertama di Buleleng. Data dikumpulkan melalui latihan menulis terbimbing dalam bentuk teks rekon. Empat langkah ditempuh dalam menganalisis data, yaitu mengidentifikasi, mengklasifikasikan, mendeskripsikan dan menjelaskan bentuk linguistik dalam tulisan siswa. Hasil penelitian memperlihatkan bahwa pengaruh bahasa ibu terhadap bahasa antara siswa antara lain adalah penggunaan tata bahasa Indonesia, penggunaan katakata Indonesia, penghilangan pemarkah jamak -s, penghilangan TO BE dan aspek kala dari verba. Pengaruh bahasa sasaran antara lain adalah padanan yang salah, penambahan kata sandang, kesalahan dalam memilih pronomina dan overgeneralisasi bentuk lampau -ed.
\end{abstract}

Kata-kata kunci: interlanguage, bahasa pertama, bahasa sasaran

\section{Abstract}

English text written by junior high school students consists of erroneous sentences which describe learners' language. Either the native language or target language influences the errors. This term is called interlanguage. The study aimed at describing the interlanguage produced by EFL students in recount text. The subjects of the study were 20 students of junior high school in Buleleng Regency. The data was collected through a guided writing exercise in the form of recount text. There were four steps in analyzing the data, namely identifying errors, classification, description, and explanation. The result shows that native language influence includes Indonesian grammar patterns, Indonesian words, wrong selection of word form, the omission of plural marker $-s$, TO BE deletion, and verb tense. Target language influence includes false friend, the addition of articles, wrong choice of pronoun, and overgeneralization of past form -ed.

Keywords: interlanguage, native language, target language

DOI: 10.26499/jk.v17i2.2719

How to cite: Adnyani, N. L. P. S., Sari, P. P. N., Suwastini, N. K. A., \& Nitiasih, P. K. (2021). Interlanguage produced by junior high school students in recount text. Kandai, 17(2), 190-203 (DOI: 10.26499/jk.v17i2.2719) 


\section{INTRODUCTION}

This study investigates interlanguage produced by junior high school students in recount text. First, the researcher focused on the students' erroneous sentences and classified them into various errors. Second, the sources of errors are identified as either those influenced by the native language (Indonesian language) or the target language (English). Interlanguage in learning English by EFL learners is a critical study that should be discussed. Selinker (1972), the first linguist to propose interlanguage terms, defined it as the features of language learners' first language (L1) and second language (L2). The terms native language and target language are synonyms to first and second language; they are interchangeable in this study. Interlanguage separates transitional linguistic systems, linguistic patterns, and rules. It explains the specific cognitive and sociolinguistics processes. Selinker (1972) argues that fossilization is also a part of interlanguage. The fossilizations contain phonological, morphological, and syntactic features in the speech of secondlanguage speakers. They are different from the target language rules even after years of instruction and exposure to the target language. Selinker (1972) presented three main characteristics of interlanguage; namely, the first is permeability which refers to the language system is permeable. It means that language rules can be changed. The second is dynamic interlanguage which means constantly changing. In other words, rules can change; for example, I goed home - I went home. The last characteristic is that interlanguage is systematic. The learner does not become aware of the language rules used, but they convey their target language using their native language structure.
Macdonald (2016) stated that learners' language acquisition, in other words, is called the development process in which the learners show dominated a common rule but do not yet know all exceptions of the structure. For instance, the learner may use the past tense marker -ed for all verbs, regular and irregular such as walked, wanted, hugged, laughed, *drinked, *hitted, *goed. Pandarangga (2014) stated that learners' interlanguage is affected by the target and first language knowledge, system, and rules. This finding denies previous arguments, which noted that the erroneous speech or written production due to interference from the native language. The study proposed pedagogical implications that teachers should be aware of their crucial roles to facilitate, guide, and lead. The related study also conducted by Chachu (2016) result-ing from that the interlanguage in French students is caused by the limitation of vocabulary or expressions, conjugation in present tense, and present continuous tense in English. Fauziati (2017) studied Indonesian EFL students' English compositions, where she found out that both the native language and target language influenced the students' interlanguage production. The study confirmed native language influence was in Indonesian borrowing, including bound cultural expression, cognates, and acronym. In contrast, the target language influenced the students' grammar, particularly verb tenses. A related cultural expression in the students' English production is confirmed by Adnyani (2012).

Furthermore, Darussalam (2013) studied learning strategy and interlanguage errors by Indonesian learners. $\mathrm{He}$ found out that overgeneralization, first language transfer, and oversimplification contributed to the students' errors. Asikin (2017) studies the analysis of 
interlanguage produced by third-grade high school students in narrative text. This study revealed that the students' interlanguage production is in passive sentences, choosing incorrect verb agreement, choosing the wrong auxiliary, making the unparalleled sentence, and translating sentence word by word. Their native language influences the students' interlanguage.

The study of interlanguage was also conducted by Handayani, Ihsan, \& Mirizon (2019). This study investigated the interlanguage analysis of syntactic and diction errors found in theses written by magister students. The study showed that the magister students made erroneous sentences in the form of syntactic errors, namely subject-verb agreement, tenses, redundancy, article, and pluralization. Meanwhile, in term of lexical errors includes the wrong selection of verb and adjective. Cheng (2015) studied the interlanguage produced by higher vocational and technological college EFL education in China. The research found that students' errors existed because of their development process, where they applied rules systems between the mother tongue and target language. They introduced new rules; adjustment, improvement, replacement, and expansion of the transitional rule system. The study uses code-mixing by the English teacher conducted by Purnamasari, Putra, \& Suwastini (2018). This study aimed at the process and the reason for mixing in the teaching process. There were several reasons for using code-mixing in the classroom, such as clarifying errors, showing care, using the appropriate word in utterance, and understanding the academic content.

Meanwhile, code-mixing also facilitates the students in understanding new terms of the target language like grammar and new vocabulary. Tiarina (2017) investigated the interlanguage error produced by freshmen. The participants were freshmen who took an intensive course. The data were obtained through multiple-choice, cloze procedures, and writing tests. The study reveals that the students' ill-forms were in grammar structures such as sentence construction, English tenses, and omission, due to the students were not aware of the English form.

In this study, errors experienced by EFL students will be observed. O'Grady, Dobrovolsky, \& Katamba (2002) classified errors in transfer errors and developmental errors. Transfer errors are related to the influence of the native language, while developmental errors reflect the effect of the target language. In various literature, the developmental error is connected with intralingual errors.

The study aims to identify, describe, and analyze the students' interlanguage in recount text. After doing the research and getting the result, it is hoped that the result will be beneficial for EFL learners to understand better the correct English structure in writing the recount text.

\section{THEORETICAL FRAMEWORK}

\section{The Nature of Interlanguage}

The term 'Interlanguage' was first introduced by Selinker (1972), who referred to it as a second language systematic knowledge independent of both first language and second language. According to Al-khresheh (2016), interlanguage is the language produced by foreign language or second language learners acquiring or learning a new language. The other definition of erroneous speech is a type of language that can be produced by EFL learners or second language learners who are acquiring or learning a new language (Al- 
Khresheh, 2015). Meanwhile, interlanguage pragmatics studies the ways non-native speakers acquire, comprehend, and use linguistics patterns or speech act in a second language.

According to Selinker (1972), five psycholinguistic processes exist in the latent psychological structure. Native language transfer, Overgeneralization of target language rules, Transfer of training, Strategies of communication, and Strategies for learning. These five processes are articulated in the following sections, one by one.

\section{The Characteristics of Interlanguage}

Selinker(1972) stated that there are
three main characteristics of
interlanguage, are follows:

\section{Permeability}

Permeability is permeable because rules that constitute the learners' knowledge at any stage are not fixed but are open to amendment. In many parts, this is a general feature of native languages. The language system is permeable. Interlanguage is has a different degree of permeability (Selinker, 1927).

\section{Dynamic}

Dynamic is continually changing. Meanwhile, the students' interlanguage is not changing immediately but rather slowly revises the interim systems to adapt new hypotheses to the target language system. Dynamic is introducing a new structure, first in a context and the other contexts. The process of constant revision and extension of rules is a feature of the inherent instability of interlanguage and its built-in propensity for change (Selinker, 1927).

\section{Systematic}

Systematic is the learner who operates according to the system of rules he has constructed up to that point. He uses one rule while he uses a different one (Selinker, 1927).

\section{Types of Interlanguage}

Language use is characterized by systematic and non-systematic variation. Ellis (1982) classifies interlanguage variability into different types, such as systematic variability, non-systematic variability. The description of each kind of interlanguage is as follows:

Systematic variability relates to linguistic context, situational context, and psychological context. If the linguistic context changes, the language learners' target language production will also change. Non-systematic variability is characterized by two types of variability, such as performance variability and free variability. Performance variability includes the failure of performance such as a slip of the tongue, false starts, a derivation from rules, and change of mind. Free variability refers to a phenomenon when language learners possess two or more forms. In the nativespeaker speech, free variability is limited. However, interlanguage has a high level of free variability, which shows that interlanguage evolves.

\section{RESEARCH METHOD}

This study is a descriptive study that focuses on the students' interlanguage forms in their writing. The framework used in this study is interlanguage analysis and error analysis. The study was conducted in a state of junior high school in Bali Province. The subjects of this study were 20 students in the 8th grade of junior high students in Singaraja who have learned English as a 
foreign language for four years through formal education. Their average age is 14-15 years old. They are homogeneous in terms of language background, nationality, level of education, English proficiency, and age. This study was carried out on students' English recount text to identify, collect, describe, and explain the data. Data were gathered through free composition with the topic of 'my activity last Sunday'. The researcher supervised the students while they wrote a recount text. It was around 10-15 sentences. Therefore, descriptive analysis was used to analyze the data. The steps identify the errors found in the students' writing, classifying all erroneous sentences based on the types, presenting the incorrect since in the number of lists, describing and explaining each data. The data were divided into two different types, namely native language influence and target language influence.

\section{DISCUSSION}

Table 1

The Frequency of Interlanguage Forms

\begin{tabular}{|c|c|c|c|}
\hline $\begin{array}{c}\text { Native } \\
\text { language } \\
\text { influence }\end{array}$ & $\mathbf{F}$ & $\begin{array}{l}\text { Target language } \\
\text { influence }\end{array}$ & f \\
\hline $\begin{array}{l}\text { Indonesian } \\
\text { grammar } \\
\text { pattern }\end{array}$ & 35 & False friend & 11 \\
\hline $\begin{array}{l}\text { Indonesian } \\
\text { words }\end{array}$ & 21 & $\begin{array}{l}\text { Overgeneralisation } \\
\text { of article }\end{array}$ & 15 \\
\hline $\begin{array}{l}\text { Wrong } \\
\text { selection of } \\
\text { word form }\end{array}$ & 12 & $\begin{array}{l}\text { Wrong choice of } \\
\text { pronoun }\end{array}$ & 18 \\
\hline $\begin{array}{l}\text { Omission of } \\
\text { plural } \\
\text { marker -s }\end{array}$ & 27 & $\begin{array}{l}\text { Overgeneralisation } \\
\text { of past form -ed }\end{array}$ & 22 \\
\hline $\begin{array}{l}\text { TO BE } \\
\text { deletion }\end{array}$ & 31 & & \\
\hline $\begin{array}{l}\text { Present } \\
\text { verbs instead } \\
\text { of past verbs }\end{array}$ & 17 & & \\
\hline Total & 143 & & 66 \\
\hline
\end{tabular}

The results mentioned in table 1 shows that native language influence had a higher range in influencing students' interlanguage than target language is affected by the intralanguage, that is, 143 cases and 66 cases.

\section{Native Language Influence (Indonesia Language)}

The erroneous sentences in students' recount text are influenced by their native language (Indonesian language). The students' mother tongue controls the target language. In this study, five native language aspects affect the students' English sentences, namely: use of Indonesian grammar pattern, use of Indonesian words, wrong selection of word form, the omission of plural marker -s, TO BE deletion, verb tense. This study corroborates earlier research that claims the native language strongly impacts students' target language production (Fauziati,2017; Kusumawardani \& Adnyani, 2017; Maheswari, Adnyani, \& Suwastini, 2020; Suwastini, Wiraningsih, \& Adnyani, 2020).

The first type of language learners' native language influence is when students adopt the Indonesian grammar pattern. The students have adequate English vocabulary required to express their meaning. However, they still use their native language grammar pattern in conveying the sense in the target language. The students tried to make sentences in English based on the vocabulary that they know. However, they combined the words using an Indonesian grammar pattern. The data where students use Indonesian grammar pattern can be seen in examples (1) until (5).

(1) Week last I went to Denpasar. Minggu lalu saya pergi ke Denpasar. 'Last week, I went to Denpasar'

(2) Price ticket 15.000

Harga tiket adalah Rp. 15.000

'The ticket's is Rp. 15.000.' 
(3) I happy go beach.

Saya senang pergi ke pantai.

'I'm happy about going to the beach.'

(4) We rest in living room.

Kami beristirahat diruang keluarga

'We are taking a rest in the living room.'

(5) After last, we went to our house.

Setelah berakhir kami kembali ke rumah.

'After it ends, we went home.'

In data (1) - (5), the students used English words in composing the sentences. However, the structure they used was Indonesian. Indonesian language, in general, is an $\mathrm{S}-\mathrm{V}-\mathrm{O}$ language. However, colloquially, its word order is very flexible. The subject does not change according to the subjects nor tenses. The flexibility of the Indonesian language word order can occur in declarative, interrogative, and imperative sentences. Besides, null subjects and objects are allowed in the Indonesian language (Adnyani, Beratha, Pastika, \& Suparwa, 2018; Cahyono, 2016; Ewing, 2005). In data (1), the phrase 'week last' has an adverbial function. However, the syntactic form is a noun phrase, where the head of the phrase is 'week' while the modifier is 'last'. This syntactic construction is the opposite of the English noun phrase pattern, where it should be 'last week.' A similar error was found in data (2), where 'price ticket' is taken from the Indonesian noun phrase pattern where 'the price' is the head and 'ticket' is the modifier. In data (3) and (4), the TO BE 'am' and 'are' are missing. It is a type of transfer error where the Indonesian language does not have BE in sentence patterns. The nonexistence of $\mathrm{BE}$ in a sentence is transferred to their English sentences. The last data, 'after last,' is translated from the Indonesian grammar pattern, which is not acceptable in English. The influence of the native language on the students' grammar is also confirmed by Choroleeva (2009).

Another native language influence is the use of Indonesian words. In this case, the students used Indonesian words in English sentences. The data can be seen in examples (6) - (9).

(6) I went to Pantai Penimbangan. Saya pergi ke Pantai Penimbangan. 'I went to Penimbangan Beach'

(7) Many wisatawan in the beach. Banyak pengunjung di pantai. 'Many tourists at the beach.'

(8) Yesterday I make PR.

Kemarin saya mengerjakan $P R$ (Pekerjaan Rumah.

'I did my homework yesterday.'

(9) My mother cooking jamur crispy last week.

Minggu lalu Ibu saya memasak jamur goreng.

'Last week, my mother cooked somecrispy mushroom.'

In data (6) - (9), the students inserted the words 'pantai penimbangan', 'wisatawan', 'PR', and 'jamur crispy'. Those words are related to Indonesian terms or names which students borrowed and added to the English sentences. It is understandable since the students might not find the English equivalence for those words due to limited vocabulary. Language learners tend to produce lexical items from two languages (Purnamasari, Putra, \& Suwastini, 2018). Thus, they had difficulty translating those terms into English.

Another native language influence is the wrong selection of word form. When EFL learners produced English sentences, they tried to use their target language vocabulary even though they 
were not suitable. The wrong selection of word form can be seen in examples (10) and (11).

(10) I dinner in Tanjung Alam.

Saya makan malam di Tanjung Alam.

'I have dinner in Tanjung Alam'

(11) I lunch in home.

Saya makan malam dirumah.

'I have lunch at home.'

The sentences in data (10) and (11) showed that noun is used as verbs. The students assumed that 'dinner' and 'lunch' are verbs, while they are nouns. The word 'dinner' in Indonesian is translated into makan malam. The word 'lunch' is translated to makan siang. Makan malam and makan siang are verb phrases in Indonesian. Therefore, the students regard the word 'dinner' and 'lunch' as verbs.

The next native language influence on the students' interlanguage production is the plural marker -s is deleted. The students omit plural markers -s because the plural form in the Indonesian pattern does not need any affixes. The data of omission of the plural marker -s can be seen in examples (12) - (15).

(12) I bought some souvenir in Krishna. Saya membeli beberapa cenderamata di Krishna.

'I bought some souvenirs in Krishna'

(13) I saw a lot of dolphin in Lovina beach.

Saya melihat banyak lumba-lumba di pantai Lovina.

'I saw a lot of dolphins in Lovina Beach.'

(14) Last week, I played football with my friend.

Minggu lalu saya bermain sepak bola dengan teman-teman saya.
'Last week, I played football with my friends'

(15) I saw many animal in the zoo.

Saya melihat banyak binatang dikebun binatang.

'I saw many animals in the zoo.'

Indonesian and English have a different pattern in plural form. In Indonesian, to form a plural can be done by reduplicating a word, for instance, anak-anak 'kids', pohon-pohon 'trees', bunga-bunga 'flowers'. Another way of forming a plural is by adding numbers or adverbs like dua anak 'two kids', banyak buah 'many fruits', beberapa buku 'some books'. Therefore, when the students miss the - s plural marker in their English sentences, the reasons can be that they transferred the non-existence of English suffixes into their English sentences. Pudin, Storey, Len, Swanto, and Din (2015) reveal that one of the most common errors in students' English writing is pluralization, a native language interference.

Deleting TO BE is also an influence of the native language. In Indonesian sentences, TO BE does not exist. In this case, when the learners develop their target language, they tend to omit to TO $\mathrm{BE}$ in a sentence. The data of TO BE deletion can be seen in examples (16) (20).

(16) My activity on Sunday fishing and playing football.

Kegiatan saya pada hari minggu adalah memancing dan bermain sepak bola.

'My activities on Sunday are fishing and playing football.'

(17) At 1 o'clock we hungry. Pada pukul 1 kita sudah lapar 'At 1 o'clock, we were hungry.' 
(18) It nice trip. I feel very happy.

Liburan yang menyenangkan. Saya sangat Bahagia.

'It was a nice trip. I was very happy.'

(19) The zoo interesting place to visit. Kebun binatang adalah tempat yang menarik untuk dikunjungi

'The zoo was an interesting place to visit.'

(20) That great day for my family.

Pada saat itu adalah hari yang menyenangkan bagi keluarga saya.

'It was a great day for my family.'

The sentences in data (16) - (20) are categorized as interlanguage because the students do not put TO BE after the subjects. This finding corroborates the study conducted by Sari, Budasi, Adnyani \& Suwastini (2021). TO BE in English are 'am, is, are, was, and were'. Those TO BEs need to be put after the subject and followed by the object (complement) of the sentences. TO BE should be included when a subject is followed by a noun or an adjective or $\mathrm{V}$ ing. Such construction does not exist in Indonesian. In the Indonesian syntactic pattern, BE is not required. There is no $\mathrm{BE}$ form, as can be seen in the following examples.

$\begin{array}{lll}\text { Nama } & \text { saya } & \text { Putu } \\ \text { Name } & \text { I } & \text { Putu }\end{array}$

'My name is Putu.'

$\begin{array}{ll}\text { Dia } & \text { Cantik } \\ \text { She } & \text { Beautiful }\end{array}$

'She is beautiful.'

$\begin{array}{lll}\text { Kucing } & \text { itu } & \text { lapar } \\ \text { Cat } & \text { the } & \text { hungry }\end{array}$

'The cat is hungry.'

$\begin{array}{lll}\text { Dia } & \text { sedang } & \text { tidur } \\ \mathrm{He} & \text { (in a process) } & \text { sleep }\end{array}$

'He is sleeping.'
From the above examples, it can be seen that the Indonesian sentence pattern does not require any $\mathrm{BE}$. In other words, $\mathrm{BE}$ does not exist. There is no BE before a noun, an adjective, or verb continuous.

The students also tend to use a present verb instead of a past verb. The students' recount text revealed that students substituted a past verb with a present verb. Where the students applied the present tense, where they were supposed to write it in the past tense, the data using present verbs instead of past verbs can be seen in examples (21) - (23).

(21) Yesterday I go to city park.

Kemarin saya pergi ke Taman Kota.

'Yesterday, I went to the city park.

(22) On Sunday my mother and I go to market.

Pada hari minggu saya dan Ibu saya pergi ke pasar.

'On Sunday, my mother and I went to the market.'

(23) When we arrived we buy ticket.

Ketika kami sampai kemudian kami membeli tiket.

'When we arrived, we bought the ticket.'

Data (21) - (23) shows that EFL learners still have difficulties using verb tenses. According to Fauziati (2017), verb tenses are the most difficult for students to master. The present verb substituting past verbs can be understood as the Indonesian grammar pattern does not recognize verb tenses. A similar verb is used to inform something that happens in the present, past, or future. A similar finding was revealed by Na-Phuket and Othman (2015). 


\section{Target Language Influence (English Language)}

The target language also interfered with the student's language use which caused erroneous in the students' English production. It is called a developmental error or intralanguage error. It happened when the students' sentences are not the result of transfer from the first language (Indonesian language). However, it also influences the pattern of the target language they produced. The learners try to develop their target language, for example, by using the wrong choice of words, verb, and articles. The influence of the target language found in this study can be classified into four categories. They were: (1) False friend (similar in meaning), (2) Overgeneralization of article, (3) Wrong choice of pronoun, and (4) Overgeneralization of past form -ed.

\section{False Friend (Similar in Meaning)}

A false friend is also known as similar in meaning. The example of a false friend can be seen in example (24) until (25).

(24) I went to go beach.

Saya pergi ke pantai.

'I went to the beach.'

(25) My brother eats we all our foods.

Kakak saya makan semua makanan kami.

'My brother eats all our food.

EFL learners were confused with 'go', 'went' and 'gone'. Those verbs are irregular verbs used based on the tenses. The learners think that 'go', and 'went' has a different meaning. The EFL learners use the same verb in one sentence, both in English and Indonesian, that sentence is having ill-formed. The correct sentence should be 'I went to the beach.'This sentence refers to the past tense, which indicates telling the past even.

\section{Overgeneralization of Article}

The learners were confused about the use of an article in a sentence. There are sentences with the wrong addition of articles in the students' recount text. The example of incorrect articles can be seen in examples (26) until (28).

(26) I went to the beach by the car.

Saya pergi kepantai dengan mobil.

'I went to the beach by car.'

(27) My family and I went the camping in the Bedugul.

Saya dan keluarga saya pergi berkemah di Bedugul.

'My family and I went camping in Bedugul'

(28) We went there by the motorcycles.

Kita pergi kesana dengan mengendarai sepeda motor.

'We went there by motorcycles.

The sentences above showed that the learners put articles before nouns; they think every noun should begin with an article. Thus, the learner produces ill form in composing English sentences. In English, the article 'the' is used to refer to specific things or particular objects. An example of an article in a particular noun is 'let's read the magazine'. This sentence tells that the speaker persuades others to read a specific magazine and not just any magazine. The result of this study is the same as the previous research conducted by Handayani, Ihsan, \& Mirizon (2019), where they found an article is overgeneralized.

\section{Wrong Choice of Pronoun}

English has many types of pronouns. The learners are confused about the use of the pronoun in English. The example of the wrong pronoun choice can be seen in example (29) until (30). 
(29) After the me and my family went back home.

Setelah saya dan keluarga saya pulang kerumah.

'After my family and I are home.'

(30) On the first day, us set up tend for camping.

Pada hari pertama kami menyiapan tenda untuk berkemah.

'On the first day, we prepared a tent for camping.

For example (29), the sentence shows that EFL learner used the pronoun 'me' instead of 'I'. Besides, the learner also used an article before the pronoun. Pronouns are divided into five categories: subject pronoun, object pronoun, possessive adjective (determiner), possessive pronoun, and reflexive or intensive pronoun. In example (30), the pronoun 'we' is replaced by 'us'. It shows that the students are confused between the pronoun that functions as subjects and objects.

\section{Overgeneralization of Past Form-ed}

The target language influence is the overgeneralization of the past form -ed. From the data collection, several examples found that the students used the past form -ed in verbs that do not require the form. The example of overgeneralization of past form -ed can be seen in examples (31) - (35).

(31) I sleeped in the afternoon.

Saya tidur pada siang hari.

'I slept in the afternoon.'

(32) I waked up.

Saya bangun tidur.

'I woke up.'

(33) We back to home to taked a break. Kamikembali kerumah untuk beristirahat.

'We go home to take a break.'
(34) Last Sunday, I goed to my grandmother house.

Minggu lalu saya pergi kerumah nenek saya.

'Last Sunday, I went to my grandmother's house.'

(35) Yesterday, my mother buyed some foods.

Kemarin Ibu saya membeli banyak makanan.

'Yesterday, my mother bought some foods'

It can be said that the students know that they should add suffix -ed in past verb form. However, they fail to notice that the irregular form in English does not require the ending -ed. Thus, they used the rule of regular form -ed and applied it in all verbs. When a regular verb is in the past form, the suffix -ed is attached to the verb. For example, the regular verbs 'add' becomes $(\rightarrow)$ 'added', 'disappoint' $\rightarrow$ 'disappointed', 'watch' $\rightarrow$ 'watched'.

On the other hand, the irregular verbs did not need suffix -ed for the past tense. Each irregular verb has its past form. For examples 'teach' becomes $(\rightarrow)$ 'taught', 'eat' $(\rightarrow)$ 'ate', 'swim' $(\rightarrow)$ 'swam'.

Based on the data obtained through guided writing in the form of recount text, it was found that the past form -ed was overgeneralized. In example (31), the learner wrote 'sleeped' when it should be 'slept'.It means that the learner assumed that every verb should end with -ed.In example (32), the word 'wake up' in the past tense is 'woke up', but the learner wrote 'waked up'. In example (33), the phrase 'taked break' was written while it should be 'took a break'. The learner did not make a mistake in changing the verb form only, but she/he also put the to infinitive forms before the verb in the past tense. In example (34), the form 'goed' was used while it should be 'went'. The 
last was 'buyed', in which the correct verb should be 'bought'. Thus, the learner is still confused when they try to change the verb based on the tenses. These findings are related to the characteristics of interlanguage proposed by Selinker (1972), also confirmed by Song (2012). He states that dynamic interlanguage is continually changing. In other words, the dynamic is rules that can change; for example, I goed home - I went home.

This study revealed that the first language frequently influences the learners' interlanguage. Students' native language influences are classified into six categories. Those are a literal translation from the Indonesian word (using Indonesian grammar pattern), Indonesian words, wrong selection of word form, the omission of -s in plural form, BE deletion, and verb. The learners frequently translate the Indonesian sentences literally, which affects them in producing interlanguage in their sentences. The learners were also influenced by their mother tongue when they do not master adequate vocabulary, and they used the word of their mother tongue in a sentence. In this way, the students did some codemixing. It is also found that the students incorrectly select the word form. The students translate the Indonesian structure pattern into an English sentence that causes erroneous in their sentence production. The EFL learner usually makes sentences in Indonesian without using the suffix $-\mathrm{s}$ in plural form. It influenced when they were expected to write a sentence in English. The learner did not add suffix -s in plural form. The learners also did not use BE in English sentences like the sentence found in students' recount text. EFL learners forget to change a present verb into the past form. They use the simple present tense in producing past events (past tense). The result of this study was the same as the previous study conducted by
Pandarangga (2014) and Pratiwi (2020). The research showed that their native language frequently influences EFL learners are in their interlanguage production.

The learners' interlanguage is influenced by the target language, which is called intralanguage error. The influence of the target language is classified into four categories. They are false friends (similar in meaning), overgeneralizing articles, pronoun choice, and past form -ed. In false friends (identical in meaning), the learners try to make a good English sentence according to the rules, but they have added two words that have one meaning. The use of the article in an inappropriate sentence of erroneous sentences. In students' recount text, there was found that the incorrect use of pronouns. EFL learner knows that past tense is used for the past event. However, they changed the verb into a past tense incorrectly. The findings show that the students change the verb 'buy' into 'buyed'. The learners thought that all verbs can be changed into past tense forms by suffix -ed.

\section{CONCLUSION}

This study shows that both the native language and target language influence the students' errors in writing English sentences. The study shows that both the native and target languages influence the errors they experienced in writing English sentences. The native language influence is found in grammar pattern, Indonesian words, wrong selection of words, the omission of the plural marker $-\mathrm{s}$, TO BE deletion, and verb tense. The influence of the target language, on the other hand, include false friend, the addition of articles, wrong choice of pronoun, and overgeneralization of past form -ed. The conclusion drawn in this research is not 
intended for generalization. However, it is simply attributed to the subjects under study.

\section{REFERENCES}

Adnyani, N. L. P. S., Beratha, N. L. S., Pastika, I.W., \& Suparwa, I.N. (2018). The development of verbal morphology and word order in an Indonesian-German bilingual child: A case study. Topics in Linguistics, 19(1), 3353.

https://doi.org/10.2478/topling2018-0003

Adnyani, N. L. P. S. \& I. N. P. H. (2012). The influence of Balinese culture on EFL university students speaking ability. Lingua Scientia, 19(2), 13-26.

Al-khresheh, M. H. (2016). A review study of contrastive analysis theory. Journal of Advances in Humanities and Social Sciences, 2(6), 49-59. https://doi.org/10.20474/jahss2.6.5

Al-Khresheh, M. H. (2015). A review study of interlanguage theory. International Journal of Applied Linguistics and English Literature, 4(3), 123-131. https://doi.org/10.7575/aiac.ijalel. v.4n.3p. 123

Asikin, N. A. (2017). The analysis of ib 3rd grade high school students in narrative writing text. Indonesian EFL Journal, 3(1), 39. https://doi.org/10.25134/ieflj.v3i1 .652

Cahyono, B. E. H., (2016). Kalimat Inversi dalam Bahasa Indonesia. Journal Indonesian Language Education and Literature, 1(2), 173-193.
Chachu, S. (2016). I am speaking French but I am thinking in English: An analysis of errors by students of the French langauge at the univeristy of Ghana. Ghana Journal of Linguistics, 54, 37-54.

Cheng, X. (2015). Interlanguage-based error analysis in higher vocational and technological college EFL education in China. Journal of Language Teaching and Research, 6(3), 639. https://doi.org/10.17507/jltr.0603 .22

Choroleeva, K. (2009). Language transfer: Types of linguistic errors committed by francophones learning English as a second foreign language. Humanizing Language Teaching, 11(5), 110123.

Darussalam, H. (2013). Learning strategy and interlanguage errors: a case study of indonesian students learning english as a foreign language. Kajian Linguistik dan Sastra 25(1), 82-91.

Ellis, R. (1995). The study of second language acquisition. Oxford, UK: Oxford University Press.

Ewing, M., (2005). Colloquial Indonesian In: A. Alexander and N. Himmelmann, eds. The Austronesian languages of asia and Madagaskar. London: Routledge.

Fauziati, E. (2017). Native and target language influence on the students'interlanguage productions a case of Indonesian EFL compositions. Indonesian Journal of Applied Linguistics, 7(1), 54-63. https://doi.org/10.17509/ijal.v7i1. 6858 
Handayani, R., Ihsan, D., \& Mirizon, S. (2019). Interlanguage Analysis of Syntactic and Diction Errors Found in Theses Written By Magister Students. International Journal of Indonesian Education and Teaching, 3(1), 102-116. https://doi.org/10.24071/ijiet.201 9.030110

Kusumawardani, D.A.N., \& Adnyani, NLPS (2017). Distinguishing the indistinguishable of the words injured, wounded, and hurt: A corpus investigation. Lingua Scientia, $24(1), \quad 19$. https://doi.org/10.23887/ls.v24i1. 18793

Maheswari, P.A.M., Adnyani, N.L.P.S., \& Suwastini, N.K.A, (2020). Interlanguage analysis on Indonesian EFL learners , compositions. Lingua Didaktika: Jurnal Bahasa Dan Pembelajaran Bahasa, 14(2), 121-131. https://doi.org/10.24036/ld.v14i2. 108643

Macdonald, R. L. (2016). Origins of the concept of vasospasm. Stroke, 47(1), e11-e15. https://doi.org/10.1161/STROKE AHA.114.006498

Na-Phuket, P. R., \& Othman, N. B. (2015). Understanding EFL students' errors in writing. Journal of Education and Practice, 6(32), 99-106.

O'Grady, W., Dobrovolsky, M., \& Katamba, F. (2002). Contemporary Linguistics: An Introduction. Cambridge: Cambridge University Press.

Pandarangga, S. (2014). A study of errors in the third singular pronoun of simpe present tense by using interlanguage analysis as an apprcoach a case study. International Journal of English Education, 1(1), 78-94.
Pratiwi, P. D., Adnyani, N. L. P. S., \& Putra, I. N. A. J. (2020). Native and target language influence on students' interlanguage speech. Linguistika, 27(2), 109-122.

Pudin, C. S., Storey, J. M., Len, L. Y., Swanto, S., \& Din, W. A. (2015). Exploring L1 interference in the writings of Kadazandusun ESL students. Indonesian Journal of Applied Linguistics, 5(7), 54-62. https://doi.org/10.17509/ijal.v5i1. 831

Purnamasari, N. M. G., Putra, I. N. A. J., \& Suwastini, N. K. A. (2018). A Desccriptive study on the use of code mixing by the English teacher at SMAN Bali Mandara in the academic year 2014/2015. Lingua Scientia, 23(2), 1. https://doi.org/10.23887/ls.v23i2. 16070

Sari, P. P. N., Budasi, I. G., Adnyani, N. L. P. S., \& Suwastini, N. K. A. (2021). The error analysis of interlingual and intralingual interferences of the students: A case study of tourism study program. Lentera Pendidikan: Jurnal Ilmu Tarbiyah dan Keguruan, 24(1), 69-81.

Selinker, L. (1972). Interlanguage. IRAL: International Review of Applied Linguistics in Language, 3(10), 209.

Song, L. (2012). On the variability of interlanguage. Theory and Practice in Language Studies, 2(4), 778-783. https://doi.org/10.4304/tpls.2.4.7 78-783 
Suwastini, N.K.A., Wiraningsih, P., \& Adnyani, N.L.P.S. (2020). An analysis of interlanguage among EFL students' speech production in English microteaching class. The Asian EFL Journal, 27(4.5), 66-89.

https://doi.org/10.1111/fcre. 1252 0
Tiarina. Y.(2017). An interlangauge error analysis: A formative evaluation for freshmen. Lingua Didaktika, 11(2), 157-170. https://doi.org/10.24036/ld 